\title{
Strategi Komunikasi Pemerintah Kabupaten Sampang dalam Merukunkan Penganut Sunni-Syiah
}

\author{
Dwi Putri Robiatul Adawiyah ${ }^{1}$, Moch. Choirul Arif ${ }^{2}$ \\ ${ }^{1}$ Mahasiswa Komunikasi Penyiaran Islam, Pascasarjana, UIN Sunan Ampel Surabaya \\ ${ }^{2}$ Dosen Komunikasi Penyiaran Islam, Pascasarjana, UIN Sunan Ampel Surabaya \\ E-mail: putrirad@gmail.com
}

DOI: https://doi.org/10.21107/ilkom.v15i2.11477

\begin{abstract}
ABSTRAK
Penelitian ini bertujuan untuk mengetahui tentang strategi komunikasi yang dilakukan oleh Pemerintah Kabupaten Sampang dalam merukunkan penganut Sunni-Syi'ah. Metode yang digunakan dalam penelitian ini yakni metode kualitatif dengan pendekatan fenomenologi. Pendekatan fenomenologi berusaha memahami orang-orang dalam situasi tertentu yang ada kaitannya dengan suatu fenomena/peristiwa. Hasil penelitian menunjukkan Pemerintah Kabupaten Sampang menggunakan strategi persuasive dengan melibatkan berbagai pihak. Pihak-pihak yang dianggap memiliki kemampuan, pengaruh serta kredibilitas dalam menyelesaikan konflik ditunjuk sebagai mediator untuk merukunkan penganut Sunni-Syi'ah. Beberapa hal yang harus diperhatikan dalam melakukan strategi komunikasi yakni mulai dari unsur komunikator, analisis kebutuhan khalayak, pesan, uji awal materi, efek sampai pada evaluasi yang dirancang untuk mencapai tujuan komunikasi yang optimal. Hendaknya strategi memiliki tujuan agar dapat memberikan informasi kepada pembacanya yang sekaligus mudah diperbarui oleh setiap manajemen puncak dan setiap anggota organisasi. Dalam melakukan strategi komunikasi tidak menutup kemungkinan adanya faktor pendukung dan penghambat. Beberapa faktor pendukung yakni, kredibilitas komunikator dalam menyelesaikan konflik, penerapan informasi, umpan balik langsung serta evaluasi pesan. Sedangkan faktor penghambatnya meliputi perbedaan latar belakang komunikan dan tingkat pendidikan komunikan yang rendah. Hal ini menyebabkan susahnya pesan yang akan disampaikan meskipun didukung oleh bukti dan alasan yang kuat dan benar.
\end{abstract}

Kata Kunci: Strategi, Komunikasi, Pemerintah Kabupaten Sampang, Penganut Sunni-Syi'ah

\section{ABSTRACT}

This study aims to find out about the communication strategy carried out by the Sampang Regency Government in reconciling Sunni-Shi'a adherents. The method used in this study is a qualitative method with a phenomenological approach. The phenomenological approach seeks to understand people in certain situations that are related to a phenomenon/event. The results showed that the Sampang Regency Government used a persuasive strategy by involving various parties. Parties who are considered to have the ability, influence and credibility in resolving conflicts are appointed as mediators to reconcile SunniShi'a adherents. Some things that must be considered in carrying out a communication strategy are starting from the communicator element, analysis of audience needs, messages, initial testing of materials, effects to evaluations designed to achieve optimal communication goals. The strategy should have a goal so that

Cite this as :

Adawiyah, Dwi Putri Robiatul \& Moch. Choirul Arif (2021). Strategi Komunikasi Kabupaten Sampang dalam Merukunkan Penganut Sunni-Syiah. Jurnal Komunikasi, 15(2), 131-144. doi: https://doi.org/10.21107/ilkom.v15i2.11477
Article History :

Received August, $13^{\text {th }} 2021$ Acepted September, $2^{\text {th }} 2021$

() 2021 Dwi Putri Robiatul Adawiyah \& Moch. Choirul Arif 
it can provide information to its readers which is at the same time easily updated by every top management and every member of the organization. In carrying out a communication strategy, it is possible that there are supporting and inhibiting factors. Some of the supporting factors are credibility of communicators in resolving conflicts, application of information, direct feedback and message evaluation. While the inhibiting factors include differences in the background of the communicant and the low level of education of the communicant. This makes it difficult for the message to be conveyed even though it is supported by strong and correct evidence and reasons.

Keywords: Strategy, Communication, Sampang Regency Government, Sunni-Shi'a adherents

\section{PENDAHULUAN}

Kekerasan atas nama agama seringkali terjadi karena ketidaktahuan, egosentrisme dan kepentingan ideologis, semua hal itu disebabkan karena kurangnya komunikasi antara kedua belah pihak sehingga menjadi konflik satu sama lain, seperti halnya yang tercermin dalam konflik sosial berlatar belakang Agama di Ambon (1999-2002). Pada tanggal 11 September 2011 bentrokan bermula ketika tersebarnya berita hoax melalui pesan pendek (SMS) mengenai meninggalnya tukang ojek yang dibunuh oleh orang Kristen. Kabar tewasnya tukang ojek tersebut menyebar cepat di masyarakat dengan berbagai macam informasi yang simpang siur. Akibatnya, sekelompok massa pun melempari siapa saja yang melewati jalan baik itu pengendara motor maupun pejalan kaki. Di lain sisi, dari pihak polisi mengonfirmasi bahwa kematian disebabkan murni karena sepeda motor korban menabrak pohon dan tembok di daerah tempat pembuangan akhir (TPA) (Sanur Lindawaty, 2011).

Konflik selanjutnya terjadi antara sesama umat islam yakni konflik yang terjadi diantara Ahmadiyah dan massa yang terjadi pada 20 Mei 2018. Adanya penyerangan, pengrusakan terhadap 7 Kepala Keluarga yang terdiri dari 24 orang rumah Jemaah Ahmadiyah di Dusun Grepek Tanak Eat, Desa Greneng, Kec. Sakra Timur, Kabupaten Lombok Timur, Provinsi Nusa Tenggara Barat. Alasan pengrusakan terjadi disebabkan oleh karena kurangnya sikap saling memahami terhadap perbedaan yang ada. Kejadian tersebut pada akhirnya berujung pada pemaksaan bahkan sampai pada ancaman pengusiran dari daerah tempat tinggal (Aziz, 2018). di sisi lain terdapat konflik yang terjadi antara pengikut aliran Syi'ah dan Sunni di Bondowoso. Pada tanggal 24 Desember 2006, konflik berawal dari ketika kelompok Syi'ah yang dinaungi oleh JABI melakukan ritual Kumail bertepatan pada saat yang sama Kyai AM dari Sunni melakukan ijtima' di majelis zikir Kecamatan Jambesari Bondowoso. Akibatnya terjadi Demo Anti Syi'ah yang menyebabkan hancurnya 3 rumah, 1 musholla dan 1 mobil milik ketua Ikatan Jama'ah Ahlul Bait (IJABI) (samar, 2016).

Pada tahun 2009 terdapat Studi yang dilakukan oleh The Asia Foundation (TAF), Yayasan Wakaf Paramadina (YWP) dan Magister Perdamaian dan Resolusi Konflik Universitas Gadjah Mada (MPRK-UGM) Sebagaimana dikutip dalam Ida dan Dyson (2015) yang menemukan bahwa sebanyak 832 kasus keagamaan terjadi di Indonesia dalam rentang waktu tahun 1990-2008. Dalam studi tersebut tersebar konflik keagamaan dalam berbagai wilayah (Ida \& Dysons, 2015), antara lain :

Tabel 1. tersebar konflik keagamaan.

\begin{tabular}{|ccc|}
\hline No. & Provinsi & Jumlah Kasus \\
\hline 1. & DKI Jakarta & 308 \\
\hline 2. & Jawa Barat & 102 \\
\hline 3. & Sulawesi Tengah & 76 \\
\hline 4. & Jawa Timur & 65 \\
\hline
\end{tabular}

Adanya berbagai aksi penyerangan, bentrokan dan kerusuhan/amuk massa yang 
mengatasnamakan agama menjadi hal yang sangat krusial dan mendapatkan perhatian dari berbagai pihak (Yunus, 2014). Dari sini pentingnya untuk memahami berbagai sudut pandang dan perbedaan yang ada. Komunikasi sebagai salah satu alat yang membantu mewujudkannya. Dalam berbagai sistem sosial budaya, proses interaksi dan komunikasi dapat menunjukkan bagaimana hubungan dalam suatu masyarakat dapat berkembang. Pada hakikatnya manusia hidup selalu membutuhkan interaksi sosial dan komunikasi yang berhubungan antara satu dengan yang lainnya baik secara individu, kelompok maupun hidup bermasyarakat.

Dalam kasus-kasus kekerasan semacam itu ada yang bisa diselesaikan dengan baik dan tidak. Meski demikian upaya untuk menyelesaikan kasus-kasus atas nama agama itu selalu diupayakan melalui proses komunikasi yang instensif yang dilakukan oleh pihak pemerintah, tokoh agama dan tokoh masyarakat. Dari sekian banyak kasus, salah satu kasus yang mendapat sorotan publik baik secara nasional dan internasional yakni kasus kerusuhan Sunni dan Syi'ah di Sampang (Syafi, 2013). Kasus ini terjadi pada tahun 2011 yang melibatkan konflik antara pengikut aliran Sunni dan Syi'ah. Dalam beberapa riset kasus ini terjadi karena disebabkan oleh beberapa hal, salah satunya riset yang telah dilakukan oleh Ida \& Dyson: "Konflik Sunni-Syiah dan dampaknya terhadap komunikasi intra-religius" mengungkapkan bahwa terjadinya konflik Sunni dan Syi'ah disebabkan pertama, cara dakwah terhadap warga sekitar yang dilakukan oleh pemimpin Syi'ah. Kedua, kurangnya pemahaman ajaran Islam yang diyakini dan dianut oleh masyarakat setempat (Ida \& Dysons, 2015).

Beberapa hal menjadi penyebabnya yakni rendahnya tingkat pendidikan dan kemiskinan warga setempat sehingga dapat dengan mudah tunduk terhadap ajaran yang disampaikan oleh kyai/ustadz. Ketiga, adanya konflik keluarga antara Pemimpin Syi'ah dan adiknya di desa Karang Gayam dan desa Bluuran yang meluas hingga ke publik yang mengakibatkan kedua belah pihak saling mengejek, memfitnah antara satu sama lainnya sehingga berdampak pada susahnya dialog yang akan dilakukan mengenai kitab dan keyakinan. Sebenarnya ada keinginan pengikut aliran Syi'ah agar pengikut Sunni dapat menerima perbedaan yang ada namun, keinginan ini harus terhenti karena ulama dan warga menolak selama pengkut Syi'ah tidak kembali/dibaiat menjadi Sunni. Keempat, adanya peran politik diantara kedua belah pihak yang berseteru yakni Tajul Muluk dan Rois. Kondisi pun semakin memanas ketika masuknya mantan Bupati Sampang. Dan terakhir, adanya persaingan ekonomi diantara para kyai dan ustadz lokal di Kecamatan Omben dan Karang Penang Sampang.

Penelitian kedua dilakukan oleh Cahyo Pamungkas yang berjudul "Mencari Bentuk Rekonsiliasi Intra-Agama: Analisis terhadap Pengungsi Syiah Sampang dan Ahmadiyah Mataram" mengungkapkan bahwa pendekatan kultural memiliki peran penting dalam proses rekonsiliasi seperti misalnya peran aktif pemerintah dan program inklusi sosial. Untuk kasus Sunni-Syi'ah Sampang pendekatan taretan tibi merupakan salah satu alternatif gagasan untuk memperbaiki hubungan antara Syi'ah dan Sunni. Selain itu perlunya mencari mediator yang dianggap sebaga penengah dan mediator yang dapat mendamaikan antara Sunni-Syi'ah serta mengembalikan nilai-nilai kekeluargaan yang renggang pada masa konflik. Sehingga perlunya peran pemerintah untuk melakukan pendekatan kultural serta membantu laspekdam NU mencari jalan tengah atas kebuntuan komunikasi yang terjadi antara Sunni-Syi'ah (Pamungkas, 2018).

Berbagai cara untuk menyelesaikan konflik atau resolusi konflik untuk mendamaikan pihak yang bersitegang yakni antara pengikut aliran Syi'ah dan Sunni telah banyak dilakukan oleh pemerintah kota, pemerintah provinsi, tokoh agama maupun stakeholder. Berdasarkan berita yang dilansir dalam maduraindepth.com mengungkapkan bahwa terdapat perbedaan pendekatan, metode dan strategi yang telah dilakukan oleh 
pemerintah sejak tahun 2016 hingga sekarang. Jika ditelusuri lebih lanjut pada tahun 20122013 metode yang digunakan yakni right based approach (pendekatan berbasis hak) yang mana memposisikan warga sebagai pelaku kejahatan sehingga pendekatan ini dinilai kurang efektif dan justru memperburuk keadaan. Kemudian pada rentang waktu 20142015 metode pendekatan yang dilakukan pun berbeda yakni menggunakan pendekatan interesting approach (berbasis kepentingan) yang kurang membuahkan hasil maksimal. Kedua belah pihak justru saling tuding dan klaim kebenaran diantara kedua belah pihak yang bersitegang. Untuk itu mulai tahun 2016 mulai dari strategi, metode dan pendekatan yang dilakukanpun berbeda. pada tahun ini pendekatan yang digunakan yakni pendekatan inklusi yang mana berbasis pada penerimaan, pemberdayaan dan kebijakan. Selain itu, pendekatan ini juga menggunakan pendekatan kebudayaan agar dapat lebih diterima oleh masyarakat serta lebih menghadirkan peran pemerintah untuk membuat kebijakan atau bisa disebut dengan power based approach (berbasis kekuasaan) (Tirtana, 2021).

Dari berbagai paparan yang telah disampaikan di atas, kasus ini terjadi karena disebabkan oleh beberapa hal ada yang menyebutkan karena faktor persaingan antar keluarga, ada yang menyebutkan karena faktor ideologis dan ada yang menyebutkan karena faktor komunikasi yang tidak baik antara kedua belah pihak. Dalam penelitian ini lebih menekankan bahwa kasus-kasus yang terjadi disebabkan karena kurangnya komunikasi antara dua belah pihak serta diperlukannya peran mediator (pemerintah) untuk merukunkan kedua belah pihak. Sehingga riset ini lebih menekankan perspetif komunikasi untuk melihat bagaimana strategi komunikasi Pemerintah Kabupaten Sampang dalam Merukunkan Penganut Sunni-Syi'ah.

\section{Strategi Komunikasi}

Pada hakikatnya strategi memiliki pengertian yaitu perencanaan dan manajemen untuk mencapai suatu tujuan (Effendy, 2008).
Dari asal katanya strategi berasal dari bahasa Yunani yaitu "stratos" yang memiliki arti tentara dan kata "agein" berarti memimpin. bisa dikatakan strategi merupakan memimpin tentara (Cangara, 2014). Sedangkan kata komunikasi itu sendiri berasal dari bahasa latin: communicatio yang berarti "pemberitahuan" atau "pertukaran pikiran" (Ruslan, 1999). Komunikasi merupakan kegiatan untuk mentransfer lambang yang memiliki makna atau arti yang harus dipahami bersama oleh dua pihak yang terlibat dalam proses komunikasi (Fatikhin, 2013). Untuk itu, Strategi komunikasi menurut Rogers sebagaimana dikutip Cangara yakni sebagai suatu transfer ide-ide baru dalam skala yang lebih besar yang dirancang untuk mengubah tingkah laku manusia (Cangara, 2014).

Dalam komunikasi sendiri diharapkan perencana dapat melakukan strategi untuk mencapai tujuan yang dicapai ketika dihadapkan dengan berbagai persoalan, terutama ketika dikaitkan dengan penggunaan sumberdaya komunikasi yang tersedia. Dalam hal ini sebagaimana di kutip Rogers (1982) dalam Stephany membatasi pengertian strategi komunikasi merupakan suatu transfer ide-ide baru dalam skala yang lebih besar yang dirancang untuk mengubah tingkah laku manusia (Stephany, 2019). Middleton dalam Pangesti berpendapat jika "strategi komunikasi yaitu kombinasi yang terbaik dari semua elemen komunikasi mulai dari komunikator, pesan, saluran (media), penerima sampai pada pengaruh (efek) yang dirancang untuk mencapai tujuan komunikasi yang optimal" (Pangesti, 2018).

Hendaknya strategi memiliki tujuan agar dapat memberikan informasi kepada pembacanya yang sekaligus mudah diperbarui oleh setiap manajemen puncak dan setiap anggota organisasi. Terdapat enam aspek penting dalam suatu strategi, yakni pertama, apa yang akan dilaksanakan, kedua alasan melakukan hal tersebut, ketiga, siapa yang bertanggungjawab atau yang menjalankan strategi, keempat berapa banyak biaya yang harus dikeluarkan untuk mensukseskan strategi, kelima berapa lama waktu yang 
diperlukan untuk strategi operasional tersebut serta hasil apa yang diperoleh dari strategi tersebut. Pada hakikatnya strategi merupakan suatu perencanaan (planning) dan manajemen untuk mencpai tujuan tertentu dalam praktik operasionalnya.

Dari sini tentu dapat ditarik benang merah jika strategi komunikasi menjadi kunci penting dalam kehidupan. Manusia sebagai mahkluk sosial tidak dapat hidup sendiri membutuhkan orang lain untuk berinteraksi, baik berposisi sebagai individu dalam keluarga maupun sebagai anggota kelompok masyarakat. Proses komunikasi ini terjadi baik secara lisan maupun tulisan. Komunikasi antarkelompok masyarakat merupakan komunikasi yang dilakukan antara satu kelompok masyarakat dengan kelompok masyarakat lainnya. setiap kelompok masyarakat tentu memiliki perbedaan pandangan, keyakinan agama, perilaku, kebiasaan, dan budaya yang berbeda satu sama lainnya. Sepertihalnya komunikasi yang dilakukan oleh pemerintah Kabupaten Sampang kepada pengikut aliran Syi'ah dan Sunni.

\section{Tahap-Tahap Strategi Komunikasi}

Terdapat tahapan-tahapan yang harus dicapai dalam proses strategi menurut Fred R. David (David, 2002) antara lain:

\section{Perumusan strategi}

Pada tahap ini merupakan proses merencanakan dan menyeleksi berbagai strategi yang pada akhirnya menuntun pada perencanaan misi dan tujuan organisasi.

\section{Implementasi strategi}

Implementasi strategi disebut juga sebagai tindakan yang ada dalam strategi, inplementasi bernakba nenobilisasi untuk mengubah strategi yang dirumuskan menjadi suatu tindakan agar tercapai kesuksesan dalam implementasi strategi, maka dibutuhkan disiplin, motivasi dan kerja keras

\section{Evaluasi strategi}

Evaluasi strategi disini merupakan proses dimana manager membandingkan antara hasil-hasil yang diperoleh dengan tingkat pencapaian tujuan. Tahapan terakhir dari strategi yaitu mengevaluasi strategi yang telah disampaikan sebelumnya.

\section{Faktor dalam Strategi Komunikasi}

Dalam menentukan strategi komunikasi diperlukan beberapa hal elemen komunikasi yang saling berhubungan, yaitu who says what, to whom through what channels, and what effects. Strategi yang dijalankan dalam perencanaan komunikasi harus diawali dengan langkah-langkah sebagai berikut (Cangara, 2014) :

1. Memilih dan menetapkan komunikator

Komunikator menjadi sumber dan kendali semua aktivitas komunikasi. Karena itu jika suatu proses komunikasi tidak berhasil dengan baik, maka kesalahan utama bersumber dari komunikator yang tidak memahami penyusunan pesan, memilih media yang tepat dan mendekati khalyak yang menjadi target sasaran. Sebagai pelaku utama dalam aktivitas komunikasi, komunikator memegang peranan yang sangat penting. komunikator yang akan menjadi ujung tombak harus terampil berkomunikasi, kaya ide serta penuh daya kreativitas.

Ada tiga syarat yang harus dipenuhi seorang komunikator yakni, tingkat kepercayaan orang lain kepada dirinya, daya tarik dan kekuatan. Kredibilitas adalah seperangkat persepsi tentang kelebihan-kelebihan yang dimiliki seorang komunikator sehingga bisa diterima oleh target sasaran.

2. Menetapkan target sasaran dan analisis kebutuhan khalayak

Memahami masyarakat, terutama yang akan menjadi target sasaran program komunikasi merupakan hal yang sangat 
penting, sebab semua aktivitas komunikasi diarahkan kepada khalayak. Khalayaklah yang menentukan berhasil tidaknya suatu program, sebab bagaimanapun besarnya biaya, waktu dan tenaga yang dikeluarkan untuk memengaruhi khalayak, namun jika khalayak tidak tertarik pada program yang ditawarkan, maka kegiatan komunikasi yang dilakukan akan sia-sia (Cangara, 2014).

Masyarakat tidak bisa dipisahkan dengan kelompok, maka masyarakat sering dikelompokkan menurut segmentasi. Untuk mengetahui dan memahami segmentasi masyarakat, maka dipetakan berdasarkan karakteristiknya. Ada tiga cara yang bisa digunakan yaitu (Cangara, 2014):

a) Aspek sosiodemografik, mencakup usia, jenis kelamin, pekerjaan, pendidikan, tingkat pendapatan, agama, ideology, etnis, termasuk pemilihan media.

b) Aspek profil psikologis, mencakup sikap yang tercermin dari kejiwaan mastarakat, misalnya temperamen, tenang, sabar, terbuka, emosional, tidak sabar, dendam, antipasti, terus terang, tertutup. Berani, penakut.

c) Aspek karakteristik perilaku masyarakat, mencakup kebiasaan-kebiasaan yang dijalani dalam kehidupan suatu masyarakat. Misalnya agamis, santun, suka pesta dan mabuk-mabukkan, individual, jujur, tanggungjawab.

\section{Teknik menyusun pesan}

Pesan adalah segala ssuatu yang disampaikan oleh seseorang dalam bentuk symbol yang dipersepsikan dan diterima oleh komunikan dalam serangkaian makna. Terdapat dua bentuk symbol yaitu secara verbal dan non verbal. Symbol verbal pemakaiannya bisa dengan bahasa. Kalimat yang telah tersruktur dan mengandung arti inilah yang di maksud bahasa. Dengan adanya bahasa seseorang dapat mudah dimengerti dan dapat menyusun suatu pengetahuan yang logis. Seberapa bagusnya ide jika tidak disusun dengan struktur bahasa yang benar maka ide yang baik tidak dapat tersampaikan dan diterima oleh orang lain. Terdapat tiga cara teknik penyampaian pesan yaitu persuasif, informatif dan mendidik.

\section{Memilih media dan saluran komunikasi}

Mempertimbangkan karakteristik isi dan tujuan pesan yang ingin disampaikan merupakan hal yang harus dilakukan ketika memilih media komunikasi. Media di sini terdapat dua macam yaitu media lama yang terdiri dari media cetak dan media elektronik. Dalam masyarakat pesan sebaiknya disalurkan melalui media massa, misalnya surat kabar atau televisi, dan untuk kelompok tertentu digunakan saluran komunikasi kelompok. Sedangkan yang termasuk dalam media baru yaitu internet yang mana penggunaan media ini di rasa lebih efektif karena dapat menjangkau seluruh lapisan masyarakat.

\section{Uji awal materi komunikasi}

Pengujian awal diperlukan agar dapat memberikan masukan terhadap halhal yang sering tidak diperhatikan oleh pembuat rencana. Berdasarkan uji awal itu maka dapat dilakukan revisi dalam bentuk pengurangan atau penambahan terhadap hal-hal yang belum tercakup sebelum disebarluaskan kepada khalayak.

\section{METODE PENELITIAN}

Penelitian kali ini merupakan jenis penelitian kualitatif. Penelitian kualitatif merupakan penelitian yang dapat dihasilkan melalui kata-kata, tulisan atau lisan dari pelaku yang diamati (Creswell, 2009). Datadata yang ada diperoleh melalui lapangan/pengamatan langsung. Pendekatan penelitian yang digunakan yakni pendekatan 
fenomenologi. Pendekatan fenomenologi berusaha memahami orang-orang dalam situasi tertentu yang ada kaitannya dengan suatu fenomena/peristiwa.

Data yang diperoleh dari hasil observasi di analisis secara kualitatif. Sebagaimana yang dikutip Bogdan dan biglen dalam Lexy mengungkapkan analisis data yakni upaya untuk mengorganisasikan data mengenai hal yang akan diteliti (J.Moleong, 2019). Dalam penelitian ini tentang strategi komunikasi pemerintah Kabupaten Sampang dalam merukunkan penganut Sunni-Syi'ah. Terdapat tiga hal yang harus diperhatikan meliputi Reduksi Data, Penyajian Data dan Kesimpulan.

Pemilihan informan merupakan hal yang penting karena dari informanlah peneliti mendapatkan informasi tentang lapangan penelitian. Untuk itu diperlukan informan yang dapat dipercaya yang dapat memberikan penjelasan mengenai obyek penelitian, informan dalam hal ini tidak dapat dipaksa namun secara sukarela memberikan informasi yang dibutuhkan. Dalam penelitian kali ini peneliti Pemilihan objek penelitian didasarkan pada teknik purpose sampling atau sampel objektif. Tujuan sampling untuk mencari berbagai sumber untuk mencari informasi sebanyak-banyaknya (H. Wijaya, 2018). Tujuannya adalah untuk menemukan sesuatu yang unik yang didapatkan dalam wawancara. Setelah para peneliti menentukan orang dalam melalui pengambilan sampel yang bertujuan, para peneliti melanjutkannya dengan snowball sampling yang diperoleh. Snowball sampling dimulai dengan peneliti mengidentifikasi satu atau dua informan, kemudian informan memberikan saran dan seterusnya, hingga membentuk bola salju yang semakin banyak (Holloway, 2007). ini adalah:

Adapun narasumber dalam penelitian

1. Tokoh Masyarakat sekaligus Mantan Kepala Badan Kesatuan Bangsa dan Politik Kabupaten Sampang tahun 2019
2. Intelijen Keamanan Polres Sampang

3. Humas Kemenag Kabupaten Sampang

4. Kepala Badan Kesatuan Bangsa dan Politik Kabupaten Sampang

Obyek penelitian yang menjadi kajian dalam penelitian ini adalah cara/strategi komunikasi pemerintah Kabupaten Sampang dalam merukunkan penganut Sunni-Syi'ah.

\section{HASIL DAN PEMBAHASAN}

Strategi komunikasi merupakan suatu transfer ide-ide baru dalam skala yang lebih besar yang dirancang untuk mengubah tingkah laku manusia. Middleton berpendapat jika "strategi komunikasi yaitu kombinasi yang terbaik dari semua elemen komunikasi mulai dari komunikator, pesan, saluran (media), penerima sampai pada pengaruh (efek) yang dirancang untuk mencapai tujuan komunikasi yang optimal (Cangara, 2014).

Pemerintah Kabupaten Sampang memiliki tugas dan kewajiban untuk menjaga perdamaian di setiap penduduknya. Untuk itu dalam rangka merukunkan kedua belah pihak, pemerintah memiliki berbagai strategi untuk merukunkan kedua belah pihak. Berikut ini adalah rincian informan:

Tabel 2. Identitas Informan

\begin{tabular}{|lll|}
\hline Informan 1 & & \\
\hline Nama & $:$ & Rudi Setiadi \\
\hline Jabatan & $:$ & Tokoh Masyarakat \\
\hline Informan 2 & & \\
\hline Nama & $:$ & Eko Purwanto \\
\hline Jabatan & $:$ & Intelkam Polres Sampang \\
& & \\
\hline Informan 3 & & \\
\hline Nama & $:$ & Faisol Ramdhoni \\
\hline Jabatan & $:$ & Humas Kemenag Kabupaten \\
& & Sampang \\
\hline Informan 4 & & Anang Djoenaidi Santoso \\
\hline Nama & $:$ & Kepala \\
\hline Jabatan & $:$ & Kabupaten Sampang \\
& & \\
\hline
\end{tabular}




\begin{tabular}{|llll|}
\hline Informan 5 & & \\
\hline Nama & $:$ & Mawardi & \\
\hline Jabatan & $:$ & $\begin{array}{l}\text { Kasi Pendidikan } \\
\text { (Pendma) Madrasah }\end{array}$ & Kemenag \\
& & Kabupaten Sampang \\
& & \\
\hline
\end{tabular}

Pemerintah Kabupaten Sampang memilih orang-orang tersebut sebagai mediator untuk mendamaikan konflik SunniSyi'ah. Untuk itu segala informasi mengenai upaya/strategi untuk merukunkan kedua belah pihak didapatkan melalui pihak-pihak tersebut.

\section{Komunikator}

$\begin{array}{cccc}\text { Menurut } & \text { Rudi } & \text { (2021) } & \text { dalam } \\ \text { menyelesaikan } & \text { konflik } & \text { tidak } & \text { mudah, }\end{array}$ diperlukan kemauan dan kemampuan dalam menguasai medan. Baik itu kondisi geografis, psikis, social maupun ekonomi masyarakat yang sedang berkonflik. Dalam konflik pasti terdapat orang-orang penguasa yang mengendalikan konflik. Mengetahui orangorang tersebut dapat memudahkan untuk menyelesaikan konflik. Dari sini mulai digali perlahan apa yang menjadi persoalan dan rebut diwilayah konflik. Faisol (2021) berpendapat seorang komunikator hendaknya orang-orang yang dipercaya oleh masyarakat, ulung dan tentunya memiliki kemampuan untuk menyelesaikan konflik.

Di lain sisi, Eko (2021) berpendapat bahwa terdapat perbedaan pola penyelesaian yang digunakan Pemerintah Kabupaten Sampang. Jika sebelum tahun 2016 tidak ada pengutusan atau penugasan LO yang mendampingi pengungsi Syi'ah di Jemundo, maka pada tahun 2016 mulai ada pengutusan atau penugasan LO. LO sebagai representasi dari Pemerintah memiliki tugas untuk menjembatani aspirasi dari warga pengungsi mengenai berbagai persoalan. Dengan adanya penunjukan LO ini sebagai bukti hadirnya negara dalam menyelesaikan konflik.

Komunikator menjadi sumber dan kendali semua aktivitas komunikasi. Karena itu jika suatu proses komunikasi tidak berhasil dengan baik, maka kesalahan utama bersumber dari komunikator yang tidak memahami penyusunan pesan, memilih media yang tepat dan mendekati khalyak yang menjadi target sasaran. Sebagai pelaku utama dalam aktivitas komunikasi, komunikator memegang peranan yang sangat penting. komunikator yang akan menjadi ujung tombak harus terampil berkomunikasi, kaya ide serta penuh daya kreativitas. Ada tiga syarat yang harus dipenuhi seorang komunikator yakni, tingkat kepercayaan orang lain kepada dirinya, daya tarik dan kekuatan. Kredibilitas adalah seperangkat persepsi tentang kelebihan-kelebihan yang dimiliki seorang komunikator sehingga bisa diterima oleh target sasaran. Untuk itu pentingnya memilih seorang komunikator yang memiliki keterampilan yang baik dan dipercaya oleh masyarakat agar dapat mencari solusi penyelesaian konflik yang sesuai dengan kondisi masyarakat. Komunikator menjadi kunci dalam menyelesaikan konflik. Tidak adanya pengutusan komunikator sebagai penghubung dalam menangani konflik akan menyebabkan susahnya konflik terselesaikan.

\section{Analisis Kebutuhan Khalayak}

Menurut Rudi dan Eko (2021) setiap pilihan terhadap penyelesaian harus benarbenar di musyawarahkan karena dampaknya pada masyarakat luas. Pertama ribut di wilayah konflik masalah jual beli tanah tidak pernah ada surat jadi diselesaikan melalui setifikasi tanah. Kedua wilayah yang konflik selesai semua. Administrasi kependudukan bermasalah, mengajukan bantuan sulit karena tidak punya KTP ataupun memiliki KTP tapi ganda jadi diselesaikan. Ingin keluar tapi tidak mempunyai passport maka kita selesaikan isbat nikah. Jadi persoalan di selesaikan satusatu. Dalam persoalan itu pasti ada yang namanya inti persoalan.

Faisol (2021) berpendapat ketika dulu menyelesaikan masalah seputar siapa yang benar dan siapa yang salah, keduanya 
sama-sama merasa benar dan tidak mau disalahkan. Pertemuan pun diadakan sekitar 100 kali pertemuan dan pembahasannya hanya seputar pada pulang dengan baiat dan pulang tidak dengan baiat, akhirnya tidak ketemu titik temu dan menemui jalan buntu. Sampai akhirnya mulai tahun 2016 barulah merubah caranya, masyarakat sama-sama diletakkan dan diposisikan sebagai korban. Kita lakuan dialog ternyata mereka kedua belah pihak banyak yang belum punya KTP, kartu nikah kita penuhi dulu baru bicara pulang.

Memahami masyarakat, terutama yang akan menjadi target sasaran program komunikasi merupakan hal yang sangat penting, sebab semua aktivitas komunikasi diarahkan kepada khalayak. Khalayaklah yang menentukan berhasil tidaknya suatu program, sebab bagaimanapun besarnya biaya, waktu dan tenaga yang dikeluarkan untuk memengaruhi khalayak, namun jika khalayak tidak tertarik pada program yang ditawarkan, maka kegiatan komunikasi yang dilakukan akan sia-sia. Masyarakat tidak bisa dipisahkan dengan kelompok, maka masyarakat sering dikelompokkan menurut segmentasi. Untuk mengetahui dan memahami segmentasi masyarakat, maka dipetakan berdasarkan karakteristiknya. Hal ini sejalan untuk penyelesaian konflik SunniSyi'ah. Analisis kebutuhan khalayak menjadi penting untuk dilakukan dalam menyelesaikan konflik. Konflik terjadi karena ada persoalan yang mendasarinya. Untuk menyelesaikan konflik diperlukan analisis secara keseluruhan pokok persoalan mulai dari persoalan kebutuhan dasar seperti KTP, surat nikah sampai sertifikasi tanah. Jika semua ini telah diselesaikan, maka secara perlahan mulai menyentuh pada persoalan inti yang menjadi keributan selama ini.

\section{Pesan}

Menurut Rudi (2021) dalam menyampaikan pesan kepada komunikan harus memperhatikan kalimat yang akan digunakan. Tingkat pemahaman komunikan berbeda-beda. Apalagi komunikan yang dihadapi yakni masyarakat desa yang memiliki pemikiran tradisional sehingga pesan yang disampaikan harus sesuai dengan kondisi, pengetahuan dan kemampuan mereka. Eko (2021) berpendapat dalam dunia intelijen, psikologi memiliki peran yang sangat signifikan, dengan psikologi kita bisa memanfaatkan sasaran kita. Jika dikaitkan dengan penyelesaian konflik persoalannya mengenai keyakinan dan sudah mengakar pada diri mereka yang ekstrim dan radikal. Beragama radikal ini keyakinan terhadap agamanya tidak kuat. Untuk menangani hal tersebut diperlukannya diskusi secara terus menerus dengan kiasan-kiasan dan bahasabahasa, diksi-diksi yang baik disertai dengan momentum yang tepat. Hal Itu tidak akan bisa terjadi jika tidak dilakukan secara tekun. Selain itu, diikuti dengan adanya pembuktikan pelayanan terhadap mereka. Seperti misalnya membantu menyelesaikan masalah KTP, surat nikah dan sertifikat tanah.

Tidak jauh berbeda dengan yang disampaikan Anang dan Mawardi (2021) memberikan pemahaman secara perlahan agar tidak ada kalimat atau diksi yang menyalahkan salah satu pihak. Sehingga dari pesan yang disampaikan ini agar dapat menyentuh hati kedua belah pihak. Selain itu, yang harus dipahami oleh warga di Jemundo bahwa nilai yang dianut/budaya masyarakat seperti ini. Itu yang harus dipahami oleh mereka.

Pesan adalah segala sesuatu yang disampaikan oleh seseorang dalam bentuk symbol yang dipersepsikan dan diterima oleh komunikan dalam serangkaian makna. Terdapat dua bentuk symbol yaitu secara verbal dan non verbal. Symbol verbal pemakaiannya bisa dengan bahasa. Kalimat yang telah tersruktur dan mengandung arti inilah yang di maksud bahasa. Dengan adanya bahasa seseorang dapat mudah dimengerti dan dapat menyusun suatu pengetahuan yang logis. Seberapa bagusnya ide jika tidak disusun dengan struktur bahasa yang benar maka ide yang baik tidak dapat tersampaikan dan diterima oleh orang lain. Terdapat tiga 
cara teknik penyampaian pesan yaitu persuasif, informatif dan mendidik.

Penggunaan diksi-diksi atau kalimat yang akan disampaikan sangat penting untuk diperhatikan. Tidak menutup kemungkinan kedua belah pihak yang berkonflik dapat menjadi rukun kembali dengan pesan-pesan yang disampaikan dapat menyentuh hati keduanya. Pentingnya untuk memberikan pemahaman mengenai nilai yang dianut oleh suatu masyarakat menjadi hal yang penting untuk dilakukan, agar kedua belah pihak yang berkonflik yakni penganut Sunni dan Syi'ah dapat saling memahami. Konflik terjadi karena terjadi ketidakpahaman karena telah melanggar nilai yang dianut oleh suatu masyarakat. Membuat orang sadar akan perbedaan antara nilai dan perilaku mereka. Untuk itu dalam menyampaikan pesam untuk menyelesaikan konflik, faktor pertama yang harus diperhatikan oleh pemerintah yakni aspek afektif dari penganut Sunni dan Syi'ah. Aspek ini mecakup pada ranah nilai, persepsi, sikap, emosi dan nilai yang dianut oleh seseorang atau kelompok yang dilakukan dengan cara yang lembut dan memberikan nasihat dengan baik.

\section{Uji awal materi}

Eko (2021) berpendapat dalam program sertifikasi tanah ini nantinya akan dilakukan pengukuran tanah secara langsung oleh warga pengungsi. Selain untuk memenuhi kebutuhan masyarakat. Program ini juga memiliki misi tersendiri yakni untuk memetakan situasi dan kondisi masyarakat. Seperti apa pemahaman masyarakat mengenai konflik dan warga pengungsi. Pada saat pengukuran tanah warga pengungsi terjun langsung di lapangan, akhirnya mengetahui bagaimana situasi sebenarnya yang ada. Warga sebenarnya sudah jenuh, sudah sadar bahwa konflik ini tidak ada untungnya yang diusir ini tidak untung begitupun warga setempat yang mengusir juga tidak untung karena warga kehilangan keluarganya. Jadi satu rumah Syi'ahnya ada 2 ada 3. Jadi saya sampaikan kalau mereka kembali tapi ya kembalilah ke ajaran sunnah ajaran NU disitu. Setelah menguji awal baru saatnya melakukan langkah-langkah yang selanjutnya.

Faisol (2021) menyatakan jika pemerintah berusaha menyiptakan kegiatan saling bertemu. Seperi misalnya panitia pengurusan tanah dari masyarakat Karanggayam. Kemasannya ngurusin pendataan tanah. Jika diminta untuk mengunjungi murni tentu tidak akan mau. Namun, berbeda halnya jika ada tujuan seperti halnya sertifikasi tanah ini baru mau. Datadata pemilik tanah beberapa bagian merupakan milik warga pengungsi. Pertemuan-pertemuan ini kuncinya untuk silaturrahmi dengan kemasan pendataan tanah.

Menguji awal materi komunikasi untuk melihat sejauh mana respon masyarakat terhadap satu sama lain. Dari pengujian awal ini nantinya akah berpengaruh terhadap langkah-langkah yang akan di ambil Pemerintah Kabupaten Sampang untuk merukunkan kedua belah pihak.

\section{Efek}

Mempengaruhi target sasaran merupakan tujuan dari semua program komunikasi. Perubahan pengetahuan, sikap dan perilakulah pengaruh yang bisa terjadi. Pada tingkat pengetahuan, pengaruh bisa terjadi dalam bentuk perubahan persepsi dan perubahan pendapat. Sedangkan yang dimaksud dari perubahan sikap yaitu adanya perubahan internal dalam diri seseorang yang diorganisir dalam bentuk prinsip, sebagai hasil evaluasi yang dilakukannya terhadap objek. Sedangkan perubahan perilaku adalah perubahan yang terhadi dalam bentuk tindakan (Putri et al., 2020).

Menurut Eko dan Faisol (2021) pembuktian- pembuktian yang telah ditunjukkan oleh Pemerintah Kabupaten Sampang membuat masyarakat akhirnya sedikit demi sedikit luluh. Pemerintah yang selama ini di anggap tutup mata dan tidak 
peduli terhadap permasalahan mereka terkikis dengan apa yang telah mereka lihat. Pada awalnya mereka menolak kehadiran pemerintah menjadi menerima. Dari hal ini akan memudahkan untuk tahap selanjutnya. Saran-saran yang akan diberikan pemerintah akan dengan mudah diterima oleh mereka. Tujuan dari adanya program-program yang dilakukan untuk membuka mata hati kedua belah pihak mengenai satu sama lain bahwa apa yang selama ini dibayangkan tidak sesuai dengan realitanya. Anang (2021) berpendapat jika pengetahuan masyarakat telah berubah mengenai karakter, sifat dan perilaku satu sama lain maka sedikit demi sedikit akan mempermudah untuk hidup berdampingan kembali.

\section{Evaluasi}

Evaluasi merupakan metode pengkajian dan penilaian keberhasilan kegiatan komunikasi yang telah dilakukan, dengan tujuan memperbaiki atau meningkatkan keberhasilan yang telah dicapai sebelumnya. Evaluasi dilakukan dalam rangka mengukur sejauh mana keberhasilan suatu program komunikasi. Kegiatan evaluasi yang dilakukan menjadi tolak ukur dari tujuan-tujuan yang telah ditetapkan sebelumnya, apakah tercapai atau tidak, atau apakah pencapaiannya cukup tinggi atau rendah (Muslimin, 2020).

Rudi dan Eko (2021) berpendapat setiap upaya yang telah dilakukan oleh Pemerintah Kabupaten Sampang selalu dilakukan evaluasi yang menyeluruh. Jika terdapat permasalahan maka dengan segera permasalah tersebut dicari solusi jalan keluarnya. Hal ini dilakukan karena yang dihadapi oleh Pemerintah menyangkut kehidupan orang banyak.

\section{Faktor Pendukung}

Faktor pendukung yakni hal-hal yang mendukung dilakukannya strategi komunikasi. Beberapa hal yang menjadi faktor pendukung yakni, pertama:

a. Kredibilitas komunikator

Rudi dan Eko (2021) berpendapat mediator harus memiliki kredibilitas yang tinggi agar dapat dipercaya oleh komunikan. Jika dari komunikator saja tidak memiliki kredibilitas yang tinggi maka apapun yang disampaikan komunikator tidak pernah di dengan oleh komunikan.

b. Penerapan informasi

Setiap informasi yang disampaikan meminimalkan distorsi, yaitu makna pesan pertama diteruskan ke penerima berikutnya. Jadi setiap apa yang disampaikan mediator akan langsung diterapkan atau dilakukan.

\section{c. Umpan balik langsung}

Eko (2021) berpendapat adanya umpan balik langsung akan dapat memperlancar proses komunikasi yang sedang berlangsung. Seperti halnya ada program yang akan dilaksanakan oleh Pemerintah, sebagai mediator menyampaikan secara langsung akan mendapat respon yang cepat dan dengan demikian terjadi percakapan yang matang. Upaya/cara yang dilkukan Pemerintah Kabupaten Sampang dilakukan dengan bertemu langsung kedua belah pihak. Sehingga respons yang diberikan oleh kedua belah pihak langsung bisa ditanggapi secara langsung.

\section{d. Evaluasi pesan}

Rudi (2021) berpendapat pada tahap ini, penerima dan pengirim pesan akan bersama-sama mengevaluasi hasil percakapan. Oleh karena itu, jika penilaian ini disinkronkan, maka akan mengarah pada konsensus ketika menafsirkan pesan. Pahami arah pembicaraan audiens. Jadi setiap apa yang disampaikan mediator akan diklarifikasi kembali terhadap penerima pesan agar terjadinya kesamaan makna.

Setiap strategi yang dilakukan oleh Pemerintah Kabupaten Sampang pasti 
memiliki faktor pendukung dibelakangnya. Faktor pendukung ini nantinya akan mampu memperlancar Pemerintah Kabupaten Sampang dalam merukunkan penganut SunniSyi'ah yang telah lama berseteru dan bersitegang.

\section{Faktor Penghambat}

Gangguan, hambatan, kebisingan, distorsi atau noise adalah suatu hal yang wajar terjadi dalam proses komunikasi. Adanya gangguan dapat menyebabkan pesan yang disampaikan oleh komunikator kurang maksimal dan rentan menimbulkan kesalahpahaman. Secara umum hambatan yang terjadi menyebabkan komunikasi tidak efektif. Komunikasi efektif ini mengacu pada persamaan makna atau persepsi antara pemberi pesan dan penerima pesan. Hambatan dapat terjadi baik itu dari komunikator sebagai pengirim pesan, komunikan yang menerima pesan, pesan yang disampaikan maupun media yang digunakan untuk menyampaikan pesan (Liliweri, 2011).

\section{a. Perbedaan latar belakang}

Rudi dan Eko (2021) berpendapat Setiap program yang akan dilaksanakan oleh Pemerintah Kabupaten Sampang pasti menemui hambatan. Hal ini disebabkan oleh adanya perbedaan latar belakang komunikan. Pahami latar belakang dan nilai audiens. Bahkan para ahli wicara akan kesulitan untuk menembus dan mengubah pemikiran pendapat individu, terutama kelompok masyarakat atau orang lain, meskipun didukung oleh bukti dan alasan yang kuat dan benar.

\section{b. Pendidikan yang rendah}

Faisol (2021) berpendapat rendahnya tingkat pendidikan komunikan menyebabkan perbedaan pemahaman yang akan disampaikan. Untuk itu mediator harus memahami dengan siapa ia berbicara agar dapat mengambil hati dari komunikan.

Memahami komunikan yang akan di ajak berbicara sangatlah penting untuk dilakukan. Jika komunikator tidak dapat menguasai komunikan akan menyebabkan kegagalan proses komunikasi yang dilakukan. Pesan apapun yang disampaikan oleh komunikator tidak akan diterima oleh komunikan.

\section{PENUTUP}

Strategi komunikasi yang dilakukan Pemerintah Kabupaten Sampang untuk merukunkan penganut Sunni-Syi'ah yakni strategi persuasive dengan melibatkan berbagai pihak. Pihak-pihak yang dianggap memiliki kemampuan, pengaruh serta kredibilitas dalam menyelesaikan konflik ditunjuk sebagai mediator untuk merukunkan kedua belah pihak. Beberapa hal yang harus diperhatikan dalam melakukan strategi komunikasi yakni mulai dari unsur komunikator, analisis kebutuhan khalayak, pesan, uji awal materi, efek sampai pada evaluasi yang dirancang untuk mencapai tujuan komunikasi yang optimal. Hendaknya strategi memiliki tujuan agar dapat memberikan informasi kepada pembacanya yang sekaligus mudah diperbarui oleh setiap manajemen puncak dan setiap anggota organisasi.

Dalam melakukan strategi komunikasi tidak menutup kemungkinan adanya faktor pendukung dan penghambat. Beberapa faktor pendukung yakni, kredibilitas komunikator dalam menyelesaikan konflik, penerapan informasi, umpan balik langsung serta evaluasi pesan. Sedangkan faktor penghambatnya meliputi perbedaan latar belakang komunikan dan tingkat pendidikan komunikan yang rendah. Hal ini menyebabkan susahnya pesan yang akan disampaikan meskipun didukung oleh bukti dan alasan yang kuat dan benar.

\section{DAFTAR PUSTAKA}

Aziz, A. (2018, Mei). Kronologi Penyerangan Jemaat Ahmadiyah di Lombok Timur, NTB - Tirto.ID. Tirto.Id. 
https://tirto.id/kronologi-

penyerangan-jemaat-ahmadiyah-

di-lombok-timur-ntb-cKQY

Cangara, H. (2014). Perencanaan dan Strategi Komunikasi. Jakarta : Rajawali Pers.

Creswell, J. W. (2009). Research Design Pendekatan Kualitatif, Kuantitatif, dan Mixed Edisi Ketiga. Yogyakarta: Pustaka Pelajar.

David, F. R. (2002). Manajemen Strategi Konsep. Jakarta: Prenhallindo. https://onesearch.id/Author/Home? author=Fred+R.+David

Effendy, O. U. (2008). Dinamika komunikasi. Bandung: Remaja Rosdakarya.

Fatikhin, R. (2013). Cara Sukses Negosiasi dan Komunikasi. Bandung: Graha Mulia Utama.

Holloway, C. D., Immy. (2007). MetodeMetode Riset Kualitatif dalam Public Relations dan Marketing Communications. Bentang Pustaka.

Ida, R., \& Dysons, L. (2015). Konflik SunniSyiah dan dampaknya terhadap komunikasi intrareligius pada komunitas di Sampang-Madura. Vol. 28, No. 1, 33-49.

J.Moleong, L. (2019). Metode penelitian kualitatif. Bandung: Remaja Rosdakarya.

Liliweri, A. (2011). Komunikasi serba ada serba makna. Jakarta: Prenada Kencana.

Muslimin, K. (2020). Buku Ajar Komunikasi Politik. Jepara : UNISNU Press.

Pamungkas, C. (2018). Mencari Bentuk Rekonsiliasi Intra-Agama: Analisis terhadap Pengungsi Syiah Sampang dan Ahmadiyah
Mataram. Vol. 13, No. 1, 114-147. https://doi.org/10.21274/epis.2018. $\underline{13.1 .113-147}$

Pangesti, L. A. (2018). Strategi Komunikasi Divisi Public Relations PLN Distribusi Jawa Barat dalam Sosialisasi Subsidi Listrik Tepat Sasaran. Jurnal Komunikasi, 12(1), 31-39.

https://doi.org/10.21107/ilkom.v12 $\underline{\mathrm{i} 1.3713}$

Putri, V. V. P., Arsy, A. N., Kamila, R. K., Tarinanda, A. A. P., Zuhri, S., Fajriah, N., Wibowo, R. T. H., Prakoso, A. A. D., Indriani, R. O., Windari, A. T., Thomas, C., Auliya, A. Z., Annisa, M., Yusuf, M., Yulianto, A., Sadaika, S., Pramesti, W. D., Isma, M. R. A., Asrih, M. A., ... Yogia, K. Y. (2020). Teori Komunikasi Massa dan Perubahan Masyarakat. Prodi Ilmu Komunikasi Universitas Muhammadiyah Malang bekerjasama dengan Inteligensia Media (Intrans Publishing Group).

Ruslan, R. (1999). Manajemen Humas dan Manajemen Komunikasi. Jakarta: PT Raja Grafindo Persada.

Samar. (2016, Desember). Inilah Daftar Penyimpangan Ajaran Syi'ah Dengan Ahlusunnah | Mata Mata News.

https://www.matamatanews.com/in ilah-daftar-penyimpangan-ajaransyi\%E2\%80\%99ah-denganahlusunnah

Sanur Lindawaty, D. (2011). Konflik Ambon: Kajian Terhadap Beberapa Akar Permasalahan dan Solusi. Vol. 2, No. 2 , 271-297. https://scholar.googleusercontent.c om/scholar?q=cache:d4NY_06k7V EJ:scholar.google.com/\&hl=id\&as _sdt=0,5\&scioq=Konflik+Ambon: 
+ Kajian+Terhadap+Beberapa+Aka $\underline{\mathrm{r}+\text { Permasalahan+dan+Solusinya* }}$

Stephany, A. A. (2019). Strategi Komunikasi dalam

Mensosialisasikan Diversifikasi Pangan oleh Dinas Pangan, Tanaman Pangan, Holtikultural Provinsi Kaltim di Kota Samarinda. eJournal Ilmu Komunikasi, 7, 155-169. ejournal.ilkom.fisip-unmul.ac.id

Tirtana, A. (2021, February 4). Ketua Lakpesdam NU Faisal Ramdhoni Urai Perjalanan Singkat Penanganan Syiah di Sampang. https://maduraindepth.com/ketualakpesdam-nu-faisal-ramdhoniurai-perjalanan-singkatpenanganan-syiah-di-sampang
Wijaya, H. (2018). Analisis Data Kualitatif Ilmu Pendidikan Teologi. Makassar: Sekolah Tinggi Theologia Jaffray. https://www.google.co.id/books/ed ition/Analisis_Data_Kualitatif_Ilm u_Pendidikan/5AFiDwAAQBAJ?h $1=\mathrm{id} \& \mathrm{gbpv}=1 \& \mathrm{dq}=$ Pemilihan + obje k+penelitian+didasarkan+pada+tek nik+purposive+sampling\&pg=PA1 $\underline{7 \& \text { printsec }=\text { frontcover }}$

Yunus, F. M. (2014). Konflik Agama di Indonesia Problem dan Solusi Pemecahannya. Substantia: Jurnal Ilmu-Ilmu Ushuluddin, Volume 16 Nomor 2, 217-228. http://dx.doi.org/10.22373/substant ia.v16i2.4930 